\title{
TECHNIQUES BASED ON THE POLYMORPHISM OF MICROSATELLITE DNA AS TOOLS FOR CONSERVATION OF ENDANGERED POPULATIONS
}

\author{
KACZMARCZYK, D. \\ Department of Environmental Biotechnology, University of Warmia and Mazury in Olsztyn \\ Stoneczna 45G, 10-718 Olsztyn, Poland \\ (e-mail: d.kaczmarczyk@uwm.edu.pl; phone: +48-89-523-41-51)
}

(Received $18^{\text {th }}$ Jul 2018; accepted $5^{\text {th }}$ Dec 2018)

\begin{abstract}
The reduction of the size and range of populations, and the destruction of their breeding sites has led to situations in which the existence of a population depends on breeding performed by humans in controlled conditions. Such conservation and restoration work should be based on maintaining the ability of protected populations to adapt to environmental conditions. This ability is determined by genetic variation within populations as well as individual genetic characteristics specific to a given population. Managing and preserving the genetic variation of a conserved population is one of most important factors that determine the success of a conservation program. This paper reviews a method based on DNA microsatellite polymorphism and its associated techniques for detection, management and conservation of genetic variation. It covers the use of this method in detecting and monitoring changes in intrapopulation genetic variability. It also covers the usefulness of this technique in assembling breeding pairs based on their genetic profiles, evaluating genetic differences between populations, optimizing and managing genetic variation resources deposited in banks of cryopreserved gametes, and evaluating the effectiveness of programs for conservation and restoration of species. Finally, suggestions for further development of the method are included.
\end{abstract}

Keywords: biodiversity, bioinformatic tools, conservation of endangered species, genetic variation, human dependent populations, molecular techniques

\section{Introduction}

The rate of extinction of populations has been accelerating since the end of the $19^{\text {th }}$ century, especially that of populations susceptible to environmental changes caused by human activity. Reduction of population ranges, destruction of breeding sites and reduction of population sizes have led to populations that depend on breeding performed by humans in controlled conditions (Koljonen et al., 2002). After being reared in controlled conditions, individuals are released into existing populations to extend the existence of those populations (Brown and Day, 2002).

Large numbers of progeny can be obtained from a few parents by using cryoconservation techniques and artificial breeding, but this method does not take into consideration the genetic differences between parents and their impact on population fitness. Although this method can be effective if environmental conditions are optimal, it leads to gradual reduction in the genetic variation of populations, which progresses with each succeeding generation (Fraser, 2008). This decrease in variation reduces the potential of the population to adapt and makes it vulnerable to changes in environmental conditions and invasion of pathogens, and thus could pose a threat to the existence of that population (Pastor et al., 2004; Zemanová et al., 2015).

Therefore, maintaining the ability of protected populations to adapt to environmental conditions should be the basis of conservation and restoration works. This ability is determined by genetic variation, which can be estimated with molecular techniques. 
This paper reviews a method of estimating genetic variability based on DNA microsatellite polymorphism and its associated techniques, which can be used to help conserve species endangered by extinction and to solve problems in conservation biology.

The paper should serve as useful compilation of up-to-date information about this method and its applications, as well as a source of suggestions for future developments of the method.

\section{Microsatellite DNA}

Microsatellite fragments of DNA constitute a substantial part of the genome of eukaryotic organisms (Charlesworth et al., 1994; Sawera et al., 2001). They are commonly used as a marker of genetic diversity in protected populations (Nielsen and Sage, 2001; Kim et al., 2004; Jurczyk, 2006; Zemanová et al., 2015). Microsatellite DNA is also used in monitoring the genetic fitness of conserved populations and in tracking their interaction with other populations (Wąs and Wenne, 2002).

Microsatellite DNA has a number of characteristics that make it useful for these purposes. First, changes within microsatellite sequences are inherited according to Mendel's laws. Second, because changes in microsatellite fragments are not subject to natural selection, it is likely that the individuals that are heterozygous in many of the microsatellite loci may also be heterozygous in loci encoding proteins responsible for their adaptability. Thus, the degree of polymorphism of microsatellite loci is a measure of the level of genetic variability in a stock or natural population (Guichoux et al., 2011). Third, microsatellite fragments can be used as universal markers and will not be affected by chromosomal mutations, because they are evenly distributed within chromosomes (Sawera et al., 2001). Fourth, these fragments are adjacent to evolutionally preserved flanking sequences (Santana et al., 2009). The presence of these flanking sequences enables the design of short oligonucleotides (primers) and the replication of mini-microsatellite sequences using the Polymerase Chain Reaction (PCR) (Sztuba-Solińska, 2005). Finally, microsatellite DNA can be used to detect very small genetic differences between organisms. This is because microsatellite fragments are some of the most polymorphic fragments of DNA, due to the presence alleles differing in length in a given chromosomal locus. The differences in length result from variations in the number of the repeat motifs that make up a microsatellite DNA fragment (O'Conell and Wright, 1997; Kelkar et al., 2010).

\section{Advantages of Microsatellite DNA for Estimating Genetic Variability}

Although the various techniques for estimating genetic variability have their advantages, the use of microsatellite DNA for this purpose has a number of advantages that make it a method of choice in a wide range of applications. For example, single nucleotide polymorphisms (SNP) can be used in studies on genetic variation as well. The SNP technique requires the analysis of many sites of point mutations, and therefore also requires detailed knowledge of the genome of the investigated species (Fernández et al., 2005). This can be a limitation of the SNP method because the genomes of many endangered species are mostly unknown. In contrast, the region flanking a microsatellite marker is evolutionary conserved, which allows these markers to be amplified when they are present in closely-related species and genomic knowledge about one of the species is lacking. Methods based on microsatellite DNA also offer other advantages over methods based on anonymous multilocus genomic markers (RFLP, AFLP, ISSR) 
and on SNPs: the microsatellite technique is easily transferable between laboratories; it requires only limited equipment and computational facilities; it provides a high polymorphism information content (PIC) per locus; and it is highly cost efficient when only a small number of loci are needed (Bezault et al., 2012). For these reasons, microsatellites markers are likely to remain the optimal choice for a wide range of ecological and evolutionary studies (e.g., relatedness and parentage analysis, population diversity and demography assessment, noninvasive genetic analysis, and conservation) (Bezault et al., 2012).

\section{Methodological Considerations}

To properly assess genetic differences on the basis microsatellite DNA polymorphism, samples must be taken from an appropriate number of individuals (Ruzante, 1998; O'Connell and Wright, 1997). These samples need to be properly acquired and preserved. PCR primers and the PCR reaction must be properly designed, and the lengths of DNA fragments need to be measured.

Typically, the sample size for inferring the amount of genetic variation in the population is a few dozen individuals (Hart et al., 2014). The number of individuals in a sample is usually difficult to determine because it depends on the number of genetic markers used and their polymorphism (O'Connell and Wright, 1997). As the number of individuals and the number of microsatellite markers that are examined increase, the precision of the estimates of genetic differences within and between populations also increases (O'Connell and Wright, 1997). However, it can be difficult to increase the number of individuals in a study due to limited availability and increased costs. As a guideline, if at least 5 markers are used and their polymorphism varies between 5 to 10 alleles, a sample size of about 50 individuals should be used (O'Connell and Wright, 1997). In studies based on 10 polymorphic microsatellite markers, increasing the number of individuals from 50 to 100 had no significant effect in the level of genetic diversity estimated in the population (Ruzzante, 1998).

Samples for analysis of microsatellite DNA polymorphism can be collected from live individuals (Powell et al., 1996). This enables studies on commercially valuable individuals and endangered species, such as marine vertebrates (Thorpe et al., 2000) and many fish species (Kumar et al., 2007; Naik et al., 2018). If the results are used for optimizing the assemblage of individuals into breeding pairs, the individuals should be marked before sample collection, which can be done with microchip tags (Kaczmarczyk and Fopp-Bayat, 2012).

After sample collection, the tissue should be preserved until DNA extraction. Unfortunately, using $70 \%$ ethanol and then storing the tissue at $4{ }^{\circ} \mathrm{C}$ does not always successfully preserve the DNA. A much more reliable method is drying samples in a laboratory drier, placing them in paper envelopes and storing them at about $20^{\circ} \mathrm{C}$ until DNA is isolated (Kaczor, 2013).

DNA can be extracted with a phenol/chloroform extraction protocol (Sambrook et al., 1989) or DNA extraction kits, which are designed for extracting DNA from tissues like blood, muscles, etc. (Żuchowska, 2011; Kaczor, 2013; Ocampo et al., 2018), allowing various tissues to be used as a source of DNA.

To amplify microsatellite fragments with the PCR technique, primers that are complementary to the regions of DNA that flank the microsatellite are needed. The primers' sequences can be obtained from published reports on the genetic variation of a species, and from the National Center for Biotechnology Information database at 
www.ncbi.nlm.nih.gov. When studying a species with a little known genome, like the lake minnow, DNA sequencing is useful for identifying microsatellite loci (Furukawa et al., 2004; Grover and Sharma, 2016). Furthermore, because the sequences surrounding microsatellite DNA are often conserved, it is often possible to use a set of primers that have been developed for another species that is not too phylogenetically distant. For example, primer sets that were designed for use with the zebra fish (Danio rerio) or with other species of cyprinid fish such as Campostoma anomallum can be used in studies of the lake minnow (Eupalasella percnurus) (Kaczmarczyk and Żuchowska, 2011; Kaczmarczyk, 2013; Gadomski, 2013).

Microsatellites can be amplified separately, via singleplex PCR, or together in a single multiplex PCR reaction (Edwards and Gibs, 1994; Migliaro et al., 2013), which allows up to 21 genetic markers to be amplified in a single PCR reaction (Shewale et al., 2013). Multiplex PCR not only accelerates research and reduces the costs of analyses (Guichoux et al., 2011; Migliaro et al., 2013; Liu et al., 2017), but also combines well with the use of an automatic capillary DNA sequencer for detection of microsatellite DNA polymorphism. To assemble a group of genetic markers into a multiplex set, the primers need to be labelled with phosphoramide dyes at the 5 ' end so that the product of amplification of one locus can be distinguished from the product of another. Either the forward or the reverse primer should be marked in each set. If the PCR products of two or more microsatellites have a similar size range, each primer pair should be marked with a different type of phosphoramid dye (Liu et al., 2017).

Automated capillary electrophoresis is the primary method of detection of microsatellite DNA polymorphism. It can detect single nucleotide differences in DNA lengths (Butler et al., 2001), and it allows greater accuracy, speed, and reproducibility than previous methods of detecting polymorphism of microsatellite loci. Automatic capillary electrophoresis is carried out in a polyacrylamide gel that is optimized for use in a specific type of automatic DNA sequencer and for a specific method of measuring DNA fragment length (Mansor et al., 2015). It is combined with software that detects differences in the length of DNA fragments, stores the results, and can perform further analyses, such as genotyping (Dennis et al., 2010).

To meet the objectives of conservation biology, the genotyping results from the investigation of microsatellite DNA polymorphism can be subjected to mathematical and statistical analyses using various software packages. These packages can be divided into four groups. The first group comprises software that calculates indicators of genetic variation within populations and the genetic distance between populations, and compares those indicators across populations to track phylogenetic relationships. This group includes software such as ARLEQUIN (Excoffier et al., 2005; Excoffier and Lischer, 2010), MSA (Dieringer and Schlötterer, 2003), STRUCTURE (Pritchard et al., 2000; Falush et al., 2003, 2007; Hubisz et al., 2009), GENEPOP (Rousset, 2007) and others. There is some overlap between the first group and the second, which comprises programs that can estimate the likelihood of events that affect genetic variation, such as migrations, and bottleneck and founder effects; these programs include ARLEQUIN (Excoffier et al., 2005; Excoffier and Lischer, 2010), BOTTLENECK (Piry et al., 1999), STRUCTURE (Pritchard et al., 2000; Falush et al., 2003, 2007; Hubisz et al., 2009). The third group comprises software for optimal assemblage of individuals into breeding pairs, based on their genetic profiles and indicators of the genetic variation expected in their progeny, such as GENEASSEMBLAGE 1.0 (Kaczmarczyk, 2015). The fourth group comprises programs that combine the use databases and genetic 
profiling to determine the origin of individuals or commercial products, for example SPAGeDi software (Hardy and Vekemans, 2002) and COLONY (Jones and Wang, 2009).

\section{Microsatellite DNA polymorphism for conservation of endangered populations}

The uses of the analysis of DNA microsatellite polymorphism can be divided into two categories. First, genetic variation can be assessed at the intra- and interpopulation levels. This assists in identifying processes affecting genetic variation and assessing methods for maintaining and managing genetic resources, including the genetic variability of populations created in conservation programs and the restitution of extinct populations (Kim, et al., 2004; Hart et al., 2014). Second, the genetic profiles of individuals can serve a variety of other ends. For example, the survival of individuals obtained under controlled conditions can be compared to that of individuals produced via natural reproduction (ICES WGBAST, 2017). Individual genetic profiles can also be used to manage cryopreserved gamete banks, to optimize assemblage of individuals for breeding (Abdul-Muneer, 2014), and to identify interspecies hybrids (Cruz et al., 2014).

\section{Detection and monitoring of changes in intrapopulation genetic variability}

Breeding individuals from local populations under controlled conditions can increase the likelihood of breeding closely related individuals, and thus reducing the genetic variability of the population. When a small number of individuals whose relationship is unknown are used for breeding, the risk of inbreeding increases (Bentsen and Olesen, 2002). Inbreeding usually increases homozygosity (Yi et al., 2015), which may decrease allelic diversity, which may affect the adaptive ability of the population (Charlesworth and Charlesworth, 1987; Saccheri et al., 1996; Crnokrak and Roff, 1999; Hedrick and Kalinowski, 2000; Chapman et al., 2009; Nielsen et al., 2012) and may lead to expression of genetic defects encoded by recessive alleles (Charlesworth and Willis, 2009; Gao et al., 2015).

The harmful effect of inbreeding on viability and population fitness is more evident in populations than in commercial stocks (Crnokrak and Roff, 1999; Whitlock, 2004; Harrison et al., 2011) and may cause programs for conservation of endangered species to fail (FAO/UNEP, 1981; Olech, 2003; Hallerman, 2003). Estimating genetic variability based on microsatellite DNA polymorphism is thus a useful tool that can be used to determine the level of genetic diversity in a protected population. It can be used for comparisons with stable populations that do not show inbreeding depression (Kaczmarczyk and Żuchowska, 2011; Gadomski, 2013), and for detection of differences between populations that are important for their survival in their respective environments (Gadomski, 2013; Abdul-Muneer, 2014).

Based on the length of DNA fragments and genotyping results, indicators of genetic variation can be calculated. These indicators are the observed $\left(H_{o}\right)$ and expected heterozygosity $\left(H_{e}\right)$, genotypic and phenotypic diversity, the percentage of polymorphic loci (P), the average number of alleles in a locus (A) and allelic richness (R) (Min et al., 2015; Long et al., 2017). For assessing genetic variation and tracking its changes, the most important of these indicators are heterozygosity and allelic diversity (Hoban et al., 2014). Low values of $\left(H_{o}\right),\left(H_{e}\right)$ and $(\mathrm{A})$ indicate low genetic variation in the population (Szczecińska et al., 2016), and a statistically significant difference between $\left(H_{o}\right)$ and $\left(H_{e}\right)$ indicates a departure from Hardy-Weinberg equilibrium. This departure can reflect a disturbance in the genetic balance of the population, possibly connected with changes 
in population size or with non-random assemblage of individuals in reproductive pairs (Hansen et al., 2008). By comparing these indicators of genetic variation with historical data and data from other populations, the genetic diversity in a population can be assessed, and actions can be taken to counter diversity loss, if necessary (Kim et al., 2004). These indicators can be calculated with software packages such those mentioned above.

\section{Detection of the consequences of reduction of genetic variability resulting from founder and bottleneck effects}

A founder effect occurs when only a few individuals start a new population, causing the genetic variation of the new population to be only a fraction of that of the parent population (Whitlock and McCauley, 1990; Kusza et al., 2013; Rochet and Lise, 2016). A bottleneck effect might be caused by environmental changes or human activity, such as overfishing (Rochet and Lise, 2016). This temporary reduction in population size reduces the genetic variation in the population. A bottleneck effect may also result from reproduction under controlled conditions. Populations whose existence depends on reproduction in controlled conditions where a small number of parental individuals are used are especially vulnerable to genetic bottlenecks (Price and Hadfield, 2014).

The polymorphism of microsatellite DNA can be used to estimate the probability that a founder or bottleneck effect occurred, and the size of those effects (Knapen et al., 2003). To this end, microsatellite DNA fragments are used to track changes in the number of alleles, allelic frequencies and heterozygosity. Based on this data, the GarzaWilliamson (G-W index) can be calculated. This index provides information about the size of the founder or genetic bottleneck effect that probably occurred in the history of the population. It is calculated on the basis of two numbers. The first is the number of alleles of a given microsatellite, and the second is the allelic range. This range is the difference in length between the longest and the shortest fragments that contain that microsatellite. The G-W index is based on the observation that, when population size decreases, the number of alleles at a microssatelite locus is more likely to be reduced than the allelic range. Thus, the index is calculated for polymorphic loci by dividing the number of alleles of a given microsatellite in a population by its allelic range plus one. In a population that did not experience a genetic bottleneck, the $\mathrm{G}-\mathrm{W}$ index ranges from 0.8 to 1 . Values below 0.8 indicate the possibility of reduction of genetic variability, while those below 0.6 indicate a significant reduction in genetic variability due to a genetic bottleneck effect (Garza and Williamson, 2001).

As an alternative, the expected heterozygosity $\left(H_{e}\right)$ and the heterozygosity resulting from genetic drift and mutation $\left(H_{e q}\right)$ can be compared, and the distribution of allelic frequency at microsatellite loci can be determined (Cristescu et al., 2010). In this procedure, one of three models can be used: the infinite alleles model (IAM), the stepwise mutation model (SMM), or a combination of these two hypotheses, the two phase model (TPM) (Di Rienzo et al., 1994). The two phase model is based on the observation that heterozygosity and allelic frequency reflect changes in population size (Rosa de Oliveira et al., 2009). If $H_{e}$ is significantly higher than $H_{e q}$ (typically at $\mathrm{p} \leq$ 0.05) and the distribution of alleles has changed from an L-shape to shifted, then the population is likely to have been affected by a bottleneck or founder effect in the recent past (Hart et al., 2014). These calculations can be performed with BOTTLENECK software (Piry et al., 1999; Cristescu et al., 2010). 


\section{Assemblage of breeding pairs based on their genetic profiles}

Using individuals for captive breeding without knowing their genetic characteristics can lead to a progressive decline in genetic variation, because the probability of breeding individuals that are genetically similar to each other is higher than that of breeding those that differ substantially (Kaczmarczyk, 2016; Aguiar et al., 2018). The resulting offspring will have lower heterozygosity and allelic diversity than their parents, and this process is likely to progress with each successive generation (Bentsen and Olsen, 2002; Fraser, 2008). For this reason, techniques for genetic management of broodstock should be applied (Blackie et al., 2011) genetic profiles should be prepared before individuals are selected for breeding and assembled into pairs. These profiles should include information such as the individual's sex, the population it came from, and a list of the alleles of microsatellite DNA that were detected across the investigated microsatellite loci (Kaczmarczyk, 2015). These profiles can be used to produce progeny that are as genetically diverse as possible because only the individuals that genetically differ the most will be selected and assembled into breeding pairs. To find the best pairs out of many possible combinations, software like Geneassemblage 1.0 (Kaczmarczyk, 2015) can be used, which is appropriate not only for diploid organisms but also for tetraploid or partially tetraploid organisms because it calculates the expected percentage of offspring with three alleles that are the same and a fourth that differs, i.e. "weak heterozygotes" (Fopp-Bayat et al., 2015).

\section{Evaluation of genetic differences between populations}

Allelic frequency can change in response to environmental conditions. These changes cause and maintain genetic differences between populations (Higgs and Derrida, 1992) that can be essential for their survival (Barraclough and Nee, 2001). Thus, preservation of genetic diversity is important for the success of conservation programs: for example, the maintenance of the unique genetic characteristics of cheetah, lion, panther and humpback whale populations is closely related to the success of conservation programs (O'Brien, 1994; Hedrick and Fredrickson, 2010).

Genetic distance is a measure of the difference in genetic characteristics between populations and species. Interpopulation genetic differences are manifested by the occurrence of private alleles and differences in allele frequencies (Avise, 2004). Private alleles are variants of microsatellite DNA fragments specific to a given species, population or group of populations. Identification of the private alleles in an individual's genotype enables determination of the population it came from and whether it is an interspecies hybrid (Van Dongen et al., 2012). In contrast to private alleles, common alleles are detected in all studied populations (Slatkin, 1981). As the phylogenetic distance between populations increases, the number of private alleles increases, the number of common alleles decreases, and the frequencies of alleles in the respective populations differ to a greater extent (Rosenberg, 2011).

To estimate genetic distance, gene flow between populations and interrelations between species, methods based on microsatellite polymorphism can be used (McManus et al., 2015). Although a description of all of these methods is beyond the scope of this paper, more than one method should be used, and their results should be compared (Balloux and Lugon-Moulin, 2002; Haris et al., 2013). Two methods are given below as examples. 
One of the most commonly used methods is based on the fixation index $\left(\mathrm{F}_{\mathrm{ST}}\right)$. To determine the statistical significance of $F_{\mathrm{ST}}$, a permutation test is done, and the $P$-value indicates the proportion of the permutations that give an $\mathrm{F}_{\mathrm{ST}}$ greater than or equal to the observed $F_{\text {ST }}$ (Reynolds et al., 1983; Slatkin, 1995). F $_{\text {ST }}$ is proportional to the genetic differences between populations. Its value ranges from 0 to 1 , where 0 indicates no genetic distance, and 1, the largest possible difference between populations. Typically, a value of 0.05 or less indicates a very small genetic difference; 0.05-0.1 a moderate; 0.10.25 , a large; and above 0.25, a very large genetic distance (Balloux and Lugon-Moulin, 2002).

As an alternative to $\mathrm{F}_{\mathrm{ST}}$, the difference in mean size of alleles $\left(\delta \mu^{2}\right)$ can be calculated, which compares the mean allele sizes of microsatellite segments in terms of repeat number (Goldstein et al., 1995). The method is largely unaffected by differences in sample sizes, although it shows bias with small sample sizes (Ruzzante, 1998). Unlike $\mathrm{F}_{\mathrm{ST}}$, there is no upper limit to the value indicating genetic distance that is calculated by this method. A value of $\delta \mu^{2}$ above 10 indicates a very large genetic distance between populations (Goldstein et al., 1995; Harris et al., 2013). $\delta \mu^{2}$ can be estimated using MSA 4.05 (Dieringer and Schlötterer, 2003).

The genetic distance between pairs of populations and the intrapopulation genetic diversity can be represented graphically (Waser and Strobeck, 1998). The graph is based on a genetic assignment test, which determines the probability of occurrence an individual with a specific genotype in its native population versus the probability of its occurrence in another population (Larson et al., 2014; Kaczmarczyk and Wolnicki 2016). Those calculations are performed by Arlequin software (Excoffier et al 2005; Excoffier and Lischer, 2010), and can be imported into an Excel spreadsheet (Microsoft, USA) and scaled as co-ordinates in an $\mathrm{X}-\mathrm{Y}$ coordinate system. If a point representing an individual lies on the diagonal between the $\mathrm{X}$ and $\mathrm{Y}$ axes, the probability of its occurrence in its native population is the same as the probability of its occurrence in the alternative population. Points that are closer to one axis than to another have a greater probability of occurring in the population that corresponds to the nearer axis than in the other population, and the further the points are from the diagonal, the greater the probability of that individual occurring in the population that corresponds to the nearer axis. The spread of points within a cloud of points representing a group of individuals shows the degree of intrapopulational differences, and the distance between the points indicates the genetic differences between the individuals in that population (Kaczmarczyk and Wolnicki, 2016).

\section{Optimization and management of genetic variation resources deposited in banks of cryopreserved gametes}

Cryopreservation of gametes is a method for protecting the genetic resources of a population (FAO, 2012), and is used to safeguard the level of genetic variability (Yang and Tiersch, 2009) in the event of a catastrophe resulting in the extinction of the population. It is used for both endangered species and economically valuable breeds and breeding lines (Zhang, 2004; Cabrita et al., 2010).

The potential usefulness of cryopreserved gametes in protecting the genetic variability of a population depends on the genetic diversity of the individuals from which the gametes were collected (FAO, 2012). If gametes from a group of individuals are cryopreserved without taking into account the genetic differences between them, only a small part of the genetic variation in that population may be preserved. This 
could lead to a strong founder effect, resulting in a restored population with too little genetic variation to ensure its survival. Increasing the size of the group from which gametes are collected is not an ideal solution because it not only increases the cost of creating a gamete bank, but also does not always safeguard the genetic diversity of the population. This is particularly a concern for species such as the lake minnow, whose populations are characterized by low levels of genetic diversity (Kaczmarczyk and Żuchowska, 2011; Kaczmarczyk and Wolnicki, 2016).

To address the potential problem of a lack of genetic diversity in preserved gametes, genetic profiles of gamete donors can be developed using microsatellite DNA polymorphism to indicate which individuals differ the most and are especially valuable for conservation of genetic diversity in that population. This technique can be used with genomes that are relatively little investigated, and it enables maximum conservation of genetic diversity with the minimum number of samples. The resulting information can be used to assemble breeding pairs (Danchin-Burge et al., 2009) and maintain the genetic diversity of the population (Fernández et al., 2005).

\section{The polymorphism of microsatellite DNA as a tool for evaluation of the effectiveness programs for conservation and restoration of species}

Maintaining the level of genetic diversity of protected populations is one of the criteria for assessing the effectiveness of conservation programs (Stem et al., 2005), and investigations of the polymorphism of the microsatellite DNA can be used for this purpose. The results of investigations of microsatellite DNA that are obtained from samples taken from the current population can be compared with those from archival material (Abdul-Muneer, 2014), which can be formalin or paraffin-treated tissues (Shi et al., 2004; Wu, 2005) and scales (Kumar et al., 2007), or bones (Piglionica et al., 2012). Alternatively, the genetic diversity of a conserved population can be compared with that of stable populations in which there is no decrease in viability (Gadomski, 2013). It is possible to check whether the genetic variability of the newly created population of conserved species is close to that of a population that has existed for many years (Kashiri et al., 2018). It is also possible to estimate the size the founder effect involved in the creation of a new population (Gadomski, 2013).

In human-dependent species, the survival rate of individuals obtained in controlled conditions and released into the environment also indicates the effectiveness of conservation programs. In this context, microsatellite markers are used to determine whether an individual was produced by natural reproduction or human-controlled reproduction (Martínez and Fernández, 2008). A database with the genetic profiles of individuals used in reproduction and the use of SPAGeDi (Hardy and Vekemans, 2002) or COLONY software (Jones and Wang, 2009) enable estimation of the probability that an individual was produced by artificial or natural reproduction. Estimating the relative amounts of individuals produced by natural reproduction and those produced in controlled conditions indicates the relative effectiveness of natural breeding and conservation or restoration programs. This technique has been used for example in evaluation of the effect of the release of brown trout (Salmo trutta L.) obtained under hatchery conditions on the genetic characteristics of the Danish population of this species (Hansen et al., 2000) and in monitoring the effectiveness of programs for the conservation of sea trout (Salmo trutta morpha trutta) and salmon (Salmo salar) (Bartel, 2000; Wąs and Wenne, 2002; Nilsson et al., 2008; Jones et al., 2010; ICES WGBAST, 2017). 
One approach that is used in conservation programs is limited translocation, in which endangered populations are relocated to safer habitats. This method is currently used in the conservation of many species including the lake minnow (Kusznierz et al., 2006; Kaczmarczyk and Wolnicki, 2016). Because the effectiveness of this strategy depends on the degree of genetic diversity achieved by the population in the target location, the factors that decrease genetic variability, such as the founder effect, should be limited (Fraser, 2008). When the genetic characteristics of the source population and the genetic profiles of individuals are known, it is possible to minimize the size of the founder effect by choosing the optimal size and composition of the group that will be transferred (Gadomski, 2013). Furthermore, the information obtained about the source population will allow comparison of the genetic diversity of the source population with that of the newly established population, and estimation of the influence of the founder effect on the new population, which in turn allows assessment of the effectiveness of this method of species conservation.

To counteract changes in the environment due to human activities, species restoration can be employed. The main objective of these programs is to ensure that the genetic characteristics and functionality of the restored population are as close as possible to those of the original (extinct) population. To this end, individuals are selected from the available populations whose genetic characteristics are as similar as possible to those of the extinct population (Falk et al., 2001). The accuracy of this selection depends on the use of techniques such as the evaluation of genetic differences based on the polymorphism of the microsatellite DNA (Cibrian-Jaramillo et al., 2013). This technique was used, for example, in the program for restitution of Baltic salmon in Pomeranian rivers, in which evaluation of microsatellite polymorphism showed that the most similar existing population, and thus the most appropriate for use as stocking material, was the population spawning in the Daugava river (Bartel, 2001).

\section{Future directions}

Future developments in the application of microsatellites should include studies of the correlation between levels of genetic variation determined on basis of microsatellite DNA polymorphism and population fitnes. If we find that decreased genetic variation, as determined by this technique, correlates with reduced population fitness, then we will be able to use microsatellite DNA polymorphism to indicate which conservation projects should be given priority. This task will require genetic analysis of many individuals and populations, so the developement of multiplex PCR techniques for all relevant species is yet another task that should be undertaken. Finally, the future of investigations of microssatelite loci in conservation biology should involve combinations of the results of studies on intra- and interpopulation variation and genetic profiling with bioinformatic tools designed to manage genetic variation on both local and worldwide scales. Tools such as databases of genetic profiles of individuals and donors of gametes deposited in cryoconservation banks, combined with software designed to evaluate genetic similarity between individuals will be the future of conservation/restoration programs based on progeny produced in controlled conditions.

\section{Summary}

This paper has reviewed a molecular method based on analysis of the polymorphism of microsatellite DNA for use in the conservation and restoration of endangered 
populations. This method is particularly useful when the conservation or restoration work involves supporting populations with individuals obtained in controlled breeding programs. Analysis of microsatellite DNA polymorphism can be used to estimate and monitor genetic variability, and to select individuals for breeding or transfer that will maintain a safe level of genetic variation in a population. Furthermore, this method can also be used to optimize the selection of gametes for cryopreservation. The analysis of microsatellite DNA polymorphism can help not only to ensure the lasting success of conservation and restoration projects, but also to reduce costs by indicating how many individuals should be included in a project.

Acknowledgements. This work was supported by the National Science Centre in Poland within project No. 2014/15/B/NZ9/05240 for 2015-2018.

\section{REFERENCES}

[1] Abdul-Muneer, P. M. (2014): Application of Microsatellite Markers in Conservation Genetics and Fisheries Managementin: Recent Advances In Population Structure Analysis and Conservation Strategies. - Genetic Resources International, 2014: 691759.

[2] Aguiar, J. P., Fazzi-Gomes, P. F., Hamoy, I. G., Santos, S. E. B., Schneider, H., Sampaio, I. (2018): Loss of genetic variability in the captive stocks of tambaqui, Colossoma macropomum (Cuvier, 1818), at breeding centres in Brazil, and their divergence from wild populations. - Aquaculture Research 49: 1914-1925.

[3] Avise, J. C. (2004): Molecular markers, natural history and evolution. - Chapman and Hall, New York.

[4] Balloux, F., Lugon-Moulin, N. (2002): The estimation of population differentiation with microsatellite markers. - Molecular Ecology 11: 155-165.

[5] Barraclough, T. G., Nee, S. (2001): Phylogenetics and speciation. - Trends in Ecollogy and Evolution 16: 391-399.

[6] Bartel, R. (2000): Effectiveness of stocking tagged sea trout smolts into Reda River and Puck Bay. - Archives of Polish Fisheries 8: 149-159.

[7] Bartel, R. (2001): Return of salmon back to Polish waters. - Ecohydrology and Hydrobiology 1: 377-392.

[8] Bentsen, H. B., Olesen, I. (2002): Designing aquaculture mass selection programs to avoid high inbreeding rates. - Aquaculture 204: 349-359.

[9] Bezault, E., Rognon, X., Gharbi, J. F., Baroiller, F., Chevassus, B. (2012): Microsatellites cross-species amplification across some African cichlids. - International Journal of Evolutionary Biology vol. 2012, Article ID 870935.

[10] Blackie, C. T., Morrissey, M. B., Danzmann, R. G., Ferguson, M. M. (2011): Genetic divergence among broodstocks of Arctic charr Salvelinusalpinus in eastern Canada derived from the same founding populations. - Aquaculture Research 42: 1440-1452.

[11] Brown, C., Day, R. (2002): The future of stock enhancements: lessons for hatchery practice from conservation biology. - Fish and Fisheries 3: 79-94.

[12] Butler, J. M., Ruitberg, C. M., Vallone, P. M. (2001): Capillary electrophoresis as a tool for optimization of multiplex PCR reactions. - Fresenius' Journal of Analalitycal Chemistry 369: 200-205.

[13] Cabrita, E., Sarasquete, C., Martinez-Paramo, S., Robles, V., Beirao, J., Perez-Cerezales, S., Herraez, M. P. (2010): Cryopreservation of fish sperm: applications and perspectives. - Journal of Applied Ichtiology 26: 623-635. 
[14] Chapman, J. R., Nakagawa, S., Coltman, D. W., Slates, J., Sheldon, B. C. (2009): A quantitative review of heterozygosity-fitness correlations in animal populations. Molecular Ecology 18: 2746-2765.

[15] Charlesworth, B., Sniegowski, P., Stephan, W. (1994): The evolutionary dynamics of repetitive DNA in eukaryotes. - Nature 371: 215-220.

[16] Charlesworth, D., Willis, J. H. (2009): The genetics of inbreeding depression. - Nature Revews Genetic 10: 783-796.

[17] Charlesworth, D., Charlesworth, B. (1987): Inbreeding depression and its evolutionary consequences. - Annual Review of Ecology and Systematics 18: 237-268.

[18] Cibrian-Jaramillo, O. A., Hird, A., Oleas, N., Ma, H., Meerow, A. W., Francisco-Ortega, J., Griffith, M. P. (2013): What is the conservation value of a plant in a botanic garden? Using indicators to improve management of ex situ collections. - Botanical Reviews 79: 559-577.

[19] Cristescu, R., Sherwin, W. B., Handasyde, K., Cahill, V., Cooper, D. W. (2010): Detecting bottlenecks using BOTTLENECK 1.2.02 in wild populations: the importance of the microsatellite structure. - Conservation Genetics 11: 1043-1049.

[20] Crnokrak, P., Roff, D. A. (1999): Inbreeding depression in the wild. - Heredity 83: 260270.

[21] Cruz, V. P., Vera, M., Mendonça, F. F., Pardo, B. G., Martinez, P., Oliveira, C., Foresti, F. (2014): First identification of interspecies hybridization in the freshwater stingrays Potamotrygon motoro and P. falkneri (Myliobatiformes, Potamotrygonidae). Conservation Genetics 16: 241-245.

[22] Danchin-Burge, C., Palhière, I., François, D., Bibé, B., Leroy, G., Verrier, E. (2009): Pedigree analysis of seven small French sheep populations and implications for the management of rare breeds. - Journal of Animal Science 88: 505-516.

[23] Dennis, L., Deemer, C., Nelson, D. (2010): Standardized SSR allele naming and binning among projects. - Biological Techniques 5: 835-836.

[24] Dieringer, D., Schlötterer, C. (2003): Microsatellite analyzer (MSA): a platform independent analysis tool for large microsatellite data sets. - Molecular Ecology Notes 3: 167-169.

[25] Di Rienzo, A., Peterson, A. C., Garza, J. C., Valdes, A. M., Slatkin, M. (1994): Mutational processes of simple sequence repeat loci in human populations. - Proceedings of the National Academy of Sciences of the United States of America 91: 3166-3170.

[26] Edwards, M. C., Gibbs, R. A. (1994): Multiplex PCR: advantages, development, and applications. - PCR Methods and Applications 3: 65-75.

[27] Excoffier, L., Laval, G., Schneider, S. (2005): Arlequin ver. 3.0: An integrated software packane for population genetics data analysis. - Evolutionary Bioinformatics Online 1: 47-50.

[28] Excoffier, L., Lischer, H. E. (2010): Arlequin suite ver 3.5: A new series of programs to perform population genetics analyses under Linux and Windows. - Molecular Ecology Resources 10: 564-567.

[29] Falk, D. A., Knapp, E. E., Guerrant, E. O. (2001): An Introduction to Restoration Genetics. - Plant Conservation Alliance, Bureau of Land Management, US Department of Interior, US Environmental Protection Authority, http: //www.ser.org/docs/defaultdocument-library/ser_restoration_genetics.pdf?sfvrsn=0.

[30] Falush, D., Stephens, M., Pritchard, J. K. (2003): Inference of population structure using multilocus genotype data: linked loci and correlated allele frequencies. - Genetics 164: 1567-1587.

[31] Falush, D., Stephen, M., Pritchard, J. K. (2007): Inference of population structure using multilocus genotype data: dominant markers and null alleles. - Molecular Ecology Resources 7: 574-578.

[32] FAO. (2012): Cryoconservation of animal genetic resources. - FAO Animal Production and Health Guidelines No. 12. Rome. 
[33] FAO/UNEP. (1981): Conservation of the genetic resources of fish: problems and recommendations. - Report of the Expert Consultation on the genetic resources of fish. Rome, 9-13 June 1980. FAO Fisheries Technical Paper 217.

[34] Fernández, J., Villanueva, B., Pong-Wong, R., Toro, M. A. (2005): Efficiency of the use of pedigree and molecular marker information in conservation programs. - Genetics 170: 1313-1321.

[35] Fopp-Bayat, D., Kaczmarczyk, D., Szczepkowski, M. (2015): Genetic characteristics of Polish whitefish (Coregonus lavaretus maraena) broodstocks - recommendations for the conservation management. - Czech Journal of Animal Science 4: 171-177.

[36] Fraser, D. J. (2008): How well can captive breeding programs conserve biodiversity. A review of salmonids. - Evolutionary Applications 1: 535-586.

[37] Furukawa, S., Takeshima, H., Otaka, T., Mitsuboshi, T., Shirasu, K., Ikeda, D., Kaneko, G., Nishida, M., Watabe, S. (2004): Isolation of microsatellite markers by in silico screening implicated for genetic linkage mapping in Japanese purrerfish Takifugu rubripes. - Fisheries Science 70: 620-623.

[38] Gadomski, M. (2013): Genetic diversity op polish lake minnow populations (Eupallasella percnurus) based on the polymorphism of the microsatellite DNA. - Dissertation, University of Warmia and Mazury, Olsztyn, Poland.

[39] Gao, Z., Waggoner, D., Stephens, M., Ober, C., Przeworski, M. (2015): An estimate of the average number of recessive lethal mutations carried by humans. - Genetics 199: $1243-1254$.

[40] Garza, J. C., Williamson, E. G. (2001): Detection of reduction in population size using data from microsatellite loci. - Molecular Ecology 10: 305-318.

[41] Goldstein, D. B., Ruiz Linares, A., Cavalli-Sforza, L. L., Feldman, M. W. (1995): An evaluation of genetic distances for use with microsatellite loci. - Genetics 139: 463-471.

[42] Grover, A., Sharma, P. C. (2016): Development and use of molecular markers: past and present. - Critical Reviews in Biotechnology 36: 290-302.

[43] Guichoux, E., Lagache, L., Wagner, S., Chaumeil, P., Léger, P., Lepais, O., Lepoittevin C., Malausa, T., Revardel, E., Salin, F., Petit, R. J. (2011): Current trends in microsatellite genotyping. - Molecular Ecology Resources 11: 591-611.

[44] Hallerman, E. (2003): Inbreeding. - In: Hallerman, E. (ed.) Population Genetics: Prinnciples and Applications for Fisheries Scientists. American Fisheries Society, Betshesda MD.

[45] Hansen, M. M., Nielsen, E. E., Ruzzante, D. E., Bouza, C., Mensberg, K. (2000): Genetic monitoring of supportive breeding in Brown trout (Salmo trutta L.), Using microsatellite DNA markers. - Canadian Journal of Fisheries and Aquatic Sciences 57: 2130-2139.

[46] Hansen, M. M., Villanueva, B., Nielsen, E. E., Bekkevold, D. (2008): Investigating the genetics of populations. - In: Verspoor, E., Stradmeyer, L., Nielsen, J. L. (eds.) Atlantic Salmon: Genetics, Conservation and Management. Blackwell Publishing, UK.

[47] Hardy, O. J., Vekemans, X. (2002): SPAGeDi: a versatile computer program to analyse spatial genetic structure at the individual or population levels. - Molecular Ecology Notes 2: 618-620.

[48] Harris, L. N., Howland, K. L., Kowalchuk, M. W., Bajno, R., Lindsay, M. M., Taylor, E. B. (2013): Microsatellite and mtDNA analysis of Lake Trout, Salvelinus namaycush, from Great Bear Lake, Northwest Territories: impacts of historical and contemporary evolutionary forces on Arctic ecosystems. - Ecology and Evolution 3: 145-161.

[49] Harrison, X. A., Bearhop, S., Inger, R., Colhoun, K., Gudmundsson, G. A., Hodgson, D., Mcelvaine, G., Tregenza, T. (2011): Heterozygosity-fitness correlations in a migratory bird: an analysis of inbreeding and single-locus effects. - Molecular Ecology 20: 47864795.

[50] Hart, K. M., Hunter, M. E., King, T. L. (2014): Regional differentiation among populations of the Diamondback terrapin (Malaclemys terrapin). - Conservation Genetics 15: 593-603. 
[51] Hedrick, P. W., Kalinowski, S. T. (2000): Inbreeding depression in conservation biology. - Annual Review of Ecology and Systematics 31: 139-162.

[52] Hedrick, P. W., Fredrickson, R. (2010): Guidelines for genetic rescue: examples from Mexican wolves and Florida panthers. - Conservation Genetics 11: 615-626.

[53] Higgs, P. G., Derrida, B. (1992): Genetic distance and species formation in evolving populations. - Journal of Moleclar Evolution 35: 454-465.

[54] Hoban, S., Arntzen, J. A., Bruford, M. W., Godoy, J. A., Rus-Hoelzel, A., Segelbacher, G., Vilà, C., Bertorelle, G. (2014): Comparative evaluation of potential indicators and temporal sampling protocols for monitoring genetic erosion. - Evolutionary Applications 7: 984-998.

[55] Hubisz, M. J., Falush, D., Stephens, M., Pritchard, J. K. (2009): Inferring weak population structure with the assistance of sample group information. - Molecular Ecology Resources 9: 1322-1332.

[56] ICES WGBAST. (2017): Report of the Baltic Salmon and Trout. - Assessment Working Group, 27 March-4 April 2017. Gdansk, Poland.

[57] Jones, A. G., Small, C. M., Paczolt, K. A., Ratterman, N. L. (2010): A practical guide to methods of parentage analysis. - Molecular Ecology Resources 10: 6-30.

[58] Jones, O., Wang, J. (2009): COLONY: a program for parentage and sibship inference from multilocus genotype data. - Molecular Ecology Resources 10: 551-555.

[59] Jurczyk, Ł. (2006): The genetic characteristics of selected grayling populations (Thymalus thymalus Linnaeus, 1758) based on the molecular markers. - Dissertation, University of Warmia and Mazury.

[60] Kaczmarczyk, D. (2013): Cross-species amplification of selected zebrafish, central stoneroller, and finescale dace microsatellites in lake minnow. - Genetics and Molecular Research 12: 154-159.

[61] Kaczmarczyk, D. (2015): Genassemblage software, a tool for management of genetic diversity in human dependent population. - Conservation Genetics Resources 7: 49-51.

[62] Kaczmarczyk, D. (2016): Selection of optimal set of spawner-pairs Amreican paddlefish (Polyodon spathula) based on the polymorphism of microsatellite loci. - Archives of Polish Fisheries 24: 77-84.

[63] Kaczmarczyk, D., Fopp-Bayat, D. (2012): Assemblage of spawning pairs based on their individual genetic profiles - as tool for maintaining genetic variation within sturgeon populations. - Aquaculture research 44: 677-682.

[64] Kaczmarczyk, D., Wolnicki, J. (2016): Genetic diversity of the endangered cyprinid fish lake minnow Eupallasella percnurus in Poland and its implications for conservation. PLOS One 12: e168191.

[65] Kaczmarczyk, D., Żuchowska, E. (2011): Genetic diversity of two lake minnow, Eupallasella percnurus (Pall.) populations based on microsatellite DNA polymorphism. Archives of Polish Fisheries 19: 145-152.

[66] Kaczor, A. (2013): A profiles of microsatellite DNA as a tool in the management of genetic diversity in stocks of the rainbow trout. - Dissertation, University of Warmia and Mazury, Olsztyn, Poland.

[67] Kashiri, H., Shabani, A., Gorgin, S., Rezaii, M. (2018): Microsatellite DNA Marker Analysis of Genetic Variation in Wild and Hatchery Populations of Caspian Kutum (Rutilus kutum). - Turkish Journal of Fisheries and Aquatic Sciences 18: 1101-1111.

[68] Kelkar, Y. D., Strubczewski, N., Hile, S. E., Chiaromonte, F., Eckert, K. A., Makova, K. D. (2010): What is a microsatellite: a computational and experimental definition based upon repeat mutational behavior at A/T and GT/AC repeats. - Genome Biology and Evolution 2: 620-635.

[69] Kim, J. E, Withler, R. E, Ritland, C., Cheng, K. M. (2004): Genetic variation within and between domesticated chinook salmon, Oncorhynchus tshawytscha, strains and their progenitor populations. - Environmental Biology of Fishes 23: 371-378. 
[70] Knapen, D., Knaepkens, G., Bervoets, L., Taylor, M. I., Eens, M., Verheyen, E. (2003): Conservation units based on mitochondrial and nuclear DNA variation among European bullhead populations (Cottus gobio L., 1758) from Flanders, Belgium. - Conservation Genetics 4: 129-140.

[71] Koljonen, M. L., Tähtinen, J., Säisä, M., Koskiniemi, J. (2002): Maintenance of genetic diversity of Atlantic salmon (Salmo salar) by captive breeding programs and the geographic distribution of microsatellite variation. - Aquaculture 212: 69-92.

[72] Kumar, R., Singh, P. J., Nagpure, N. S., Kushwaha, B., Srivastava, S. K., Lakra, W. S. (2007): A non-invasive technique for rapid extraction of DNA from fish scales. - Indian Journal of Experimental Biology 45: 992-997.

[73] Kusza, S., Priskin, K., Ivankovic, A., Jedrzejewska, B., Podgorski, T., Jávor, A., Mihók, S. (2013): Genetic characterization and population bottle-neck in the Hucul horse based on microsatellite and mitochondrial data. - Biological Journal of the Linnean Society 109: 54-65.

[74] Kusznierz, J., Borsuk, P., Kamiński, R., Koper, M., Myszkowski, L., Popović, D., Wolnicki, J., Stanković, A. (2006): Low genetic variability among the lake minnow Eupallasella percnurus (Cypriniformes, Cyprinidae) populations in Poland. - Fisheries Management and Ecology 13: 131-134.

[75] Larson, S., Ramsey, C., Tinnemore, D., Amemiya, C. (2014): Novel microsatellite loci variation and population genetics within Leafy Seadragons, Phycodurus eques. Diversity 6: 33-42.

[76] Liu, T., Li, Q., Song, J., Yu, H. (2017): Development of genomic microsatellite multiplex PCR using dye-labeled universal primer and its validation in pedigree analysis of Pacific oyster (Crassostrea gigas). - Journal of Ocean University of China 16(1): 151-160.

[77] Long, A., Qing, Y., Gu, T., Zhu, Q., Liu, Y., Wang, Y., Yin, H., Shu, G., Zhang, Y., Lai, S., Zhao, X. (2017): Genetic variation of nine chicken breeds collected from different altitudes revealed by microsatellites. - Journal of Poultry Science 54: 18-25.

[78] Mansor, F., Zamri, L., Hamzah, S. S. (2015): Electrophoretic techniques for the detection of human microsatellite D19S884. - Malaysian Journal of Medical Sciences 22: 18-24.

[79] Martínez, P., Fernández, J. (2008): Estimating parentage relationships using molecular markers in aquaculture. - In: Schwartz, W. S. H. (ed.) Aquaculture research trends. Nova Science Publishers, Inc. New York, USA.

[80] McManus, J., Dalton, D., Kotze, A., Smuts, B., Dickman, A., Marshal, J., Keith, M. (2015): Gene flow and population structure of a solitary top carnivore in a humandominated landscape. - Ecology and Evolution 5: 335-344.

[81] Migliaro, D., Morreale, G., Gardiman, M., Landolfo, S., Crespan, M. (2013): Direct multiplex PCR for grapevine genotyping and varietal identification. - Plant Genetic Resources: Characterization and Utilization 11: 182-185.

[82] Min, J. J., Ye, R. H., Zhang, G. F., Zheng, R. Q. (2015): Microsatellite analysis of genetic diversity and population structure of freshwater mussel (Lamprotula leai). - Zoological Research 36: 34-40.

[83] Naik, V. M., Ashwath, N., Lamont, R. W., Shapcott, A. (2018): Novel Microsatellite Markers for Conservation of Australian Native Samadera bidwillii. - Open Journal of Ecology 8: 75-85.

[84] Nielsen, J. L., Sage, G. K. (2001): Microsatellite analyses of the trout of northwest Mexico. Genetica 111: 269-278.

[85] Nielsen, J. F., English, S., Goodall-Copestake, W. P., Wang, J., Walling, C. A., Bateman, A. W., Flower, T. P., Sutcliffe, R. L., Samson, J., Thavarajah, N. K., Kruuk, L. E. B., Clutton-Brock, T. H., Pemberton, J. M. (2012): Inbreeding and inbreeding depression of early life traits in a cooperative mammal. - Molecular Ecology 21: 2788-2804.

[86] Nilsson, J., Östergren, J., Lundqvist, H., Carlsson, U. (2008): Genetic assessment of Atlantic salmon Salmo salar and sea trout Salmo trutta stocking in a Baltic Sea river. Journal of Fish Biology 73: 1201-1215. 
[87] O'Brien, S. J. (1994): A role for molecular genetics in biological conservation. Proceedings of the National Academy of Sciences of the United States of America 91: 5748-5755.

[88] O'Connell, M., Wright, J. M. (1997): Microsatellite DNA in Fishes. - Reviews in Fish Biology and Fisheries 7: 331-363.

[89] Ocampo, R., Cardona, H., Martínez, R. (2016): Genetic diversity of Colombian sheep by microsatellite markers. - Chilean Journal of Agricultural Research 76: 40-47.

[90] Olech, W. (2003): Influence of individual inbreeding and inbreeding of mother on survival of calves of European bison (Bison bonasus). - Treatises and Monographs, Wydawnictwo SGGW, Warszawa. (In Polish with English summary).

[91] Pastor, T., Garza, J. C., Allen, P., Amos, W., Aguilar, A. (2004): Low Genetic Variability in the Highly Endangered Mediterranean Monk Seal. - Journal of Heredity 4: 291-300.

[92] Piglionica, M., De Donno, A., Baldassarra, S. L., Santoro, V., Scorca, A., Introna, F., Dell'erba, A. (2012): Extraction of DNA from bones in cases where expectations for success are low. - American journal of forensic medicine and pathology 33: 322-327.

[93] Piry, S., Luikart, G., Cornuet, J. M. (1999): BOTTLENECK: A computer program for detecting recent reductions in effective population size from allele frequency data. Journal of Heredity 4: 502-503.

[94] Powell, W., Machary, C., Provan, J. (1996): Polymorphism revealed by simple sequence repeats. - Trends in Plant Science 7: 215-222.

[95] Price, M. R., Hadfield, M. G. (2014): Population genetics and the effects of a severe bottleneck in an ex situ population of critically endangered Hawaiian tree snails. - PLoS ONE 9: e114377.

[96] Pritchard, J. K., Stephens, M., Donnelly, P. (2000): Inference of population structure using multilocus genotype data. - Genetics 155: 945-959.

[97] Reynolds, J., Weir, B. S., Cockerham, C. C. (1983): Estimation for the coancestry coefficient: basis for a short-term genetic distance. - Genetics 105: 767-779.

[98] Rochet, M. J., Lise, M. (2016): Effect of fishing on Populations. - In: Jakobsen, T., Fogarty, M. J., Megrey, B. A., Moksness, E. (eds.) Fish Reproductive Biology: Implications for Assessment and Management. Wiley-Blackwell, UK.

[99] Rosa de Oliveira, L., Meyer, D., Hoffman, J., Majluf, P., Morgante, J. S. (2009): Evidence of a genetic bottleneck in an El Nino affected population of South American fur seals, Arctocephalus australis. - Journal of the Marine Biological Association of the United Kingdom 89: 1717-1725.

[100] Rosenberg, N. A. (2011): A Population-Genetic Perspective on the Similarities and Differences among Worldwide Human Populations. - Human Biology 83: 659-684.

[101] Rousset, F. (2007): GENEPOP '007: a complete re-implementation of the GENEPOP software for Windows and Linux. - Molecular Ecology Resources 8: 103-106.

[102] Ruzzante, D. E. (1998): A comparison of several measures of genetic distance and population structure with microsatellite data: bias and sampling variance. - Canadian Journal of Fisheries and Aquatic Sciences 55: 1-14.

[103] Saccheri, I., Brakefield, P. M., Nichols, R. A. (1996): Severe inbreeding depression and rapid fitness rebound in the butterfly Bicyclus anyana (Satyridae). - Evolution 50: 20002013.

[104] Sambrook, J., Fritsch, E. F., Maniatis, T. (1989): Molecular cloning: a laboratory manual. - 2nd ed., Cold Spring Harbor Laboratory Press, Cold Spring Harbor, N.Y.

[105] Santana, Q. C., Coetzee, M. P. A., Steenkamp, E. T., Mlonyeni, O. X., Hammond, G. N. A., Wingfield, M. J., Wingfield, B. (2009): Microsatellite discovery by deep sequencing of enriched genomic libraries. - Biotechniques 46: 217-223.

[106] Sawera, M., Gruszczyńska, J., Świderek, W. (2001): Characteristics of the microsatellite markers. - Przegląd Hodowlany 4: 3-4. (in Polish with English abstract).

[107] Shewale, J. G., Wang, D., Zhong, C., Gopinath, S., Mulero, J., Razdan, A., Vijaychander, S., Deng, J., McClurg, P., Dallett, C., Minn, A. (2013): From sample collection to report 
generation - A new integrated workflow solution for paternity and relationship testing. Forensic Science International 4: e232-e233.

[108] Shi, S. R., Datar, R., Liu, C., Wu, L., Zhang, Z., Cote, R. J., Taylor, C. R. (2004): DNA extraction from archival formalin-fixed, paraffin-embedded tissues: heat-induced retrieval in alkaline solution Histochem. - Cell Biology 122: 211-218.

[109] Slatkin, M. (1981): Estimating levels of gene flow in natural populations. - Genetics 99: 323-335.

[110] Slatkin, M (1995): A measure of population subdivision based on microsatellite allele frequencies. - Genetics 139: 457-462.

[111] Stem, C., Margoluis, R., Salfasky, N., Brown, M. (2005): Monitoring and evaluation in conservation: A review of trends and approaches. - Conservation Biology 19: 295-309.

[112] Szczecińska, M., Sramko, G., Wołosz, K., Sawicki, J. (2016): Genetic diversity and population structure of the rare and endangered plant species Pulsatilla patens L.) Mill in East Central Europe. - PloS One 11: e0151730.

[113] Sztuba-Solińska, J. (2005): The systems of molecular markers and thier aplication in the agriculture. - Kosmos 2-3: 227-239. (in Polish).

[114] Thorpe, J. P., Sole-Cava, A. M., Watts, P. C. (2000): Exploited marine invertebrates: genetics and fisheries. - Hydrobiologia 420: 165-184.

[115] Van Dongen, W. F. D., Vásquez, R. A., Winkler, H. (2012): The use of microsatellite loci for accurate hybrid detection in a recent contact zone between an endangered and a recently-arrived hummingbird. - Journal of Ornithology 153: 585-592.

[116] Wąs, A., Wenne, R. (2002): Genetic differentiation bewteen hatchery and wild sea trout (Salmo trutta) in the Southern Baltic at microsatellite loci. - Aquaculture 204: 493-506.

[117] Waser, P. M., Strobeck, C. (1998): Genetic signatures of interpopulation dispersal. TREE 13: 43-44.

[118] Whitlock, M. C., McCauley, D. E. (1990): Some population genetic consequences of colony formation and extinction: Genetic correlations within founding groups. Evolution 44: 1717-1724.

[119] Whitlock, M. C. (2004): Selection and drift in metapopulations. - In: Hanski, I., Gaggiotti, O. E. (eds.) Ecology, genetics and evolution of metapopulations. Elsevier Academic Press, Burlington, U.S.

[120] Wu, X. (2005): The loss of genetic diversity in the Chinese paddlefish Psephurus gladius Martens) as revealed by genetic fingerprinting. - Journal of Genetics 84: 323-327.

[121] Yang, H., Tiersch, T. (2009): Current status of sperm cryopreservation in biomedical research fish models: zebrafish, medaka, and xiphophorus. - Comparative Biochemistry and Physiology 149: 224-232.

[122] Yi, T. L., Fang, L., Liang, X. F., Sun, L. F., Li, J., Luo, X. N., Guo, W. J., Dou, Y. Q., Sun, J. (2015): Characterization of microsatellite markers and their correlations with growth traits in Mandarin fish (Siniperca chuatsi). - Genetics and Molecular Research 14: 8926-8934.

[123] Zemanová, B., Hájková, P., Hájek, B., Martínková, N., Mikulíček, P., Zima, J., Bryja, J. (2015): Extremely low genetic variation in endangered Tatra chamois and evidence for hybridization with an introduced alpine population. - Conservation Genetics 16: 729-741.

[124] Zhang, T. (2004): Cryopreservation of gametes and embryos of aquatic species. - In: Fuller, B. J., Lane, N., Benson, E. E. (eds.) Life in the Frozen State. Boca Rosa: CRC Press.

[125] Żuchowska, E. (2011): Analysis of the genetic variation in selected populations of the lake minnow Eupallasella percnurus) based on the polymorphism of the microssatellite DNA. - Dissertation, University of Warmia and Mazury. 